\title{
Primary school teachers perception of technological pedagogical content knowledge in online learning due to Covid 19
}

\author{
Junita Cristi Makawawa ${ }^{1}$, Ali Mustadi ${ }^{1}$, Jewish Van Septriwanto ${ }^{1}$, Falenthino Sampouw ${ }^{1}$, \\ Roeth A.O Najoan ${ }^{2}$ \\ ${ }^{1}$ Universitas Negeri Yogyakarta. Jl. Colombo No.1, Yogyakarta 55281, Indonesia \\ ${ }^{2}$ Universitas Negeri Manado. Jl. Raya Tondano, Koya, Tondano Sel., Minahasa, 95618, Indonesia \\ *Corresponding Author. E-mail: junitacristi.2019@student.uny.ac.id
}

Received: 22 October 2020; Revised: 13 November 2020; Accepted: 30 December 2020

\begin{abstract}
Primary school teachers need to have technological knowledge, pedagogical knowledge, and content knowledge in online teaching. TPACK is an integrative and transformative knowledge that teachers need to use technology effectively and efficiently in the classroom. This article investigates primary school teachers' perceptions of Technological Pedagogical Content Knowledge (TPACK) competencies in implementing online learning due to the pandemic COVID-19. The sample in this study were 117 primary school teachers in North Sulawesi province. The method used is a quantitative descriptive approach. Data was collected using a questionnaire on a Likert scale developed in Google Form. The results showed that most primary school teachers in North Sulawesi, Indonesia, already had TPACK competencies in online learning during the COVID-19 pandemic. Even so, TPACK competencies are in need to be improved in the abilities of TK and PK. The correlation results between the TPACK constructs also showed that the PK and TPK components had a significant effect on TPACK primary school teachers' perception of online learning. It was also found that there was no significant difference between gender and TPACK competency of primary school teachers.
\end{abstract}

Keywords: primary school teachers' perception, TPACK, online learning, COVID 19.

How to Cite: Makawawa, J., Mustadi, A., Septriwanto, J., Sampouw, F., \& Najoan, R. (2021). Primary school teachers perception of technological pedagogical content knowledge in online learning due to Covid 19. Jurnal Prima Edukasia, 9(1), 85-95. doi:https://doi.org/10.21831/jpe.v9i1.35245

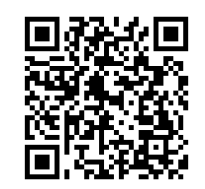

\section{Introduction}

Technology is an essential component in teaching and learning (Zelkowski, Gleason, Cox \& Bismarck, 2013). Integrating Information and Communication Technologies (ICT) into classroom teaching and learning is challenging for many primary school teachers (Kim, 2009). Teachers are expected to use technology in the classroom and knowledge that provides an appropriate environment with appropriate teaching strategies and techniques to facilitate and support students' learning (Çetin \& Erdoğan, 2018). Successful teachers in the 21st century are those who can provide knowledge using appropriate teaching and technology strategies in the classroom (Lin, Tsai, Chai, \& Lee, 2013). As studies conducted by the OECD, 2010; UNESCO 2011; Wake \& Whittingham, 2013, which investigated the mastery of technology for elementary school teachers, demonstrated teachers' technological ability to plan and implement learning activities to improve children's learning in class.

Koehler and Mishra (2009) argue that it is essential for teachers to have technological knowledge, pedagogical knowledge, and content knowledge to be sufficient. TPACK is knowledge to use various technologies in teaching and representing content (Baran et al. 2011). This knowledge refers to knowledge that effectively and efficiently uses technology to improve the effectiveness and quality of instruction in the entire teaching process, from planning to evaluating the teaching process (Ozudogru, 2019). TPACK is more than just adding technology to the teaching process and content area (Koehler \& Mishra, 2005). However, teacher knowledge is related to what, how, and why technology is used and how to integrate technology in the classroom, as reported by various researchers (Gu et al., 2013; Mishra \& Koehler 2006; Orlando \& Attard 2016). It is not enough to provide new technological tools for primary school teachers; they also need to know how to use them and their objective teaching strategies 
Jurnal Prima Edukasia, 9 (1), 2021 - 86

Junita Cristi Makawawa, et al

to meet students' various needs. The main objective of TPACK is to align technology with the subject matter and the delivery of teaching methods as a supplement in learning (Mishra \& Koehler 2006). The TPACK framework can evaluate technology's capabilities and constraints in the classroom and possible changes in learning practices and implementation (Sobel \& Grotti 2013; Tokmak 2013). Students can share stories actively while using a different digital approach to expressing themselves (Duveskog et al., 2012). Gu et al. (2013) found a difference between how teachers and students use technology and how they perceive technology's importance. As a result, this knowledge can help teachers prepare more motivating lessons with adequate resources, considering multimedia activities to digitally reach students (Lenters \& Winters 2013; Wake \& Whittingham 2013). Besides, teachers of digital natives can understand and communicate better with them (Orlando \& Attard 2016).

The knowledge of TPACK school teachers used in the classroom can increase student involvement and motivation in learning (Landry, 2010; Ricardo, 2019). It is also impactful on the relationships between the various parts of the TPACK components and how teachers provide a more positive experience for teachers and students (Hsueh-Hua \& Chao, 2011; Jang \& Tsai 2013; Chai, 2011). NCTM states that students can develop various representations of teaching material concepts in classrooms with technology. Several previous studies have linked TPACK with age and length of teaching (Lin et al., 2013; Chuang and Ho, 2011) or gender (Liu et al., 2015; Lin et al., 2013). However, very little research has been conducted to examine the effect of gender on elementary school teacher TPACK and the correlation between the TPACK framework in supporting the current implementation of online learning and its advantages during the COVID 19 pandemic.

TPACK primary school teachers' ability is a crucial part affecting online learning implementation during a pandemic. As challenges and changes in the world of education in Indonesia, it can be seen nowadays; COVID-19 enforces online learning or online learning from home in every school (Kemendikbud, 2020), and how teachers have trained their TPACK skills with the implementation of online learning. In recent years, learning online has become an essential topic in primary school education; its use expands access to learning by replacing face-to-face learning (Ke \& Hoadley, 2020). Learning that is carried out online uses the internet network with accessibility, connectivity, flexibility, and the ability to bring up various learning interactions (Moore, Dickson \& Galyen, 2011; Tsai \& Machado, 2001). Online learning provides a growing and preferred learning option for all students (Allen, Seaman, Poulin, \& Straut, 2016; Scooble, Israel, \& Benioff, 2014; Sher, Williams, \& Northcote, 2015). It also provides a choice of new technologies for content through various libraries' availability (Flood, Heath, \& Lapp, 2015). However, the use of online learning has its challenges. Previous studies have identified the lack and limitations of TPACK teachers' competencies to provide teaching quality and build meaningful learning experiences for children as one of the fundamental barriers to online learning (Harrington \& Loffredo, 2010). Although some primary school teachers make effective use of technology in their classroom practices, others seem to be far away from integrated technology. Therefore, it is considered necessary for teachers to investigate teachers' perceptions of technology integration (Graham, 2011).

The increasing need for online learning and the lack of surveys available to determine teacher TPACK perceptions in online learning implementation during the current pandemic get our attention to investigate TPACK primary school teachers' ability in online learning today. Are there significant differences between TPACK constructions in the current online learning implementation? Furthermore, is there a substantial difference between the TPACK competency of primary school teachers and male or female teachers? It is then expected that this research can help maximizing student learning by providing quality online learning experiences.

\section{Method}

This study applied a quantitative descriptive approach by conducting a survey. The survey model's main purpose is to describe the population's characteristics (Frankel \& Watlen, 2006). Participants in this study were 117 primary school teachers in the province of North Sulawesi, Indonesia. The survey response rate of $88.67 \%$. The survey respondents were mostly women $(n=90,76.92 \%)$. The mean age of the research participants was 30.93 years. The teachers were experienced enough to have an average of 3.18 years of teaching experience in primary schools. The TPACK instrument is a questionnaire with a Likert scale (Gray, 2010). This instrument was validated with Pearson's product-moment and obtained 
Jurnal Prima Edukasia, 9 (1), 2021 - 87

Junita Cristi Makawawa, et al

45 valid items with reliability of 0.935 with TK (0.628); PK (0.848), CK (0.824), TPK (0.908), TCK (0.798), PCK (0.879), TPCK (0.859) which shows a reliable TPACK instrument.

\subsection{Indicator of Technological Pedagogical Content Knowledge (TPACK)}

TPACK is a teacher's knowledge that exceeds the knowledge of content, pedagogy, and technology. However, the knowledge arises from the complex relationships between three things: mastery of the material, how to teach the material, and how to apply teaching styles to accommodate technology use. The TPACK framework has been used as a theoretical basis for developing surveys to understand teacher TPACK perceptions (Mishra \& Koehler, 2006; Ozudogru, 2019; Urbina \& Polly, 2017).

2.1a Technological Knowledge (TK) is teachers' knowledge of various technologies ranging from simple technology0 to sophisticated technology and the ability to use it in education. Indicators of this aspect include knowledge of technology in learning and the ability to use technology. (Koehler, Mishra, \& Cain, 2013; Kurk, 2018; Schmidt et al., 2014).

2.1b Pedagogical Knowledge (PK) is the teacher's knowledge of the process and various learning methods, including knowledge about how students learn, classroom management, developing and implementing learning designs, and conducting assessments of the learning process. Indicators of this aspect include knowledge of various approaches/strategies/methods/techniques/learning models, how students learn, develop, and implement lesson plans, class management, evaluation, and remedial. (Schmidt et al., 2014).

2.1c Content Knowledge (CK) is the teacher's knowledge of facts, concepts, theories, and procedures or organized frameworks on the subject being taught. Indicators of this aspect include facts in mathematics, concepts and theories in elementary school materials, and procedures in elementary school materials. (Kurt, 2018).

2.1d Technological Pedagogical Knowledge (TPK) is teachers' knowledge of technology, general pedagogical strategies, knowledge of how pedagogical activities can be integrated with technology, and how technology can change the way teachers teach. Indicators of this aspect include the suitability of technology with the approach/strategy/method/technique/model of learning; technology influences the way teachers learn. (Cox \& Graham, 2009; Schmid, et al, 2009).

2.1e Technological Content Knowledge (TCK) is knowledge about how content and technology are related, where technology and content influence and limit each other, which results in how technology can be used to create a representation of a specific topic in a particular subject. This aspect indicator represents concepts using technology (Koehler, Mishra, \& Cain, 2013).

2.1f Pedagogical Content Knowledge (PCK) combines pedagogical knowledge and content covering the teaching and learning process, curriculum, assessment, and pedagogy, knowing the teaching approach that fits certain content, how content elements are organized, well represented, and presented to students, knowledge of the causes of a complicated or comfortable topic to learn, to understand students' initial knowledge. Indicators of this aspect are learning strategies suitable for specific topics in mathematics, structured learning flow, causes of difficult or easy topics to learn, students' initial knowledge, curriculum, and assessment (Koehler, Mishra, \& Cain, 2013).

2.1g Technological Pedagogical Content Knowledge (TPCK) is teacher knowledge that is resulted from complex interactions between the necessary knowledge components (content, pedagogy, and technology) and transcends this three knowledge. TPCK includes knowledge about using technology to represent a concept, teaching content with pedagogical techniques using technology, knowledge of why a concept is difficult or easy to learn, and how technology can help fix problems faced by students; knowledge of students' prior knowledge and epistemological theories; and how technology can be used to build on existing knowledge and develop new understandings or strengthen old knowledge. The indicator of this aspect is the teaching of a concept with pedagogical techniques that use technology, technology as a medium to overcome student difficulties in learning, the use of technology in building student knowledge, and the use of technology in conducting assessments (Cox \& Graham, 2009; Schmidt et al., 2009).

\section{Results and Discussion}

This study investigates the perception of TPACK of the majority of primary school teachers in North Sulawesi in the current implementation of online learning according to the sub-domain of the 
Jurnal Prima Edukasia, 9 (1), 2021 - 88

Junita Cristi Makawawa, et al

TPACK framework. This study is essential to understanding how teachers can develop and apply pedagogical skills, content, and technological abilities that support 21st-century learning (Wefusa, 2015). Our literature review reveals that there is much research on the TPACK knowledge of elementary school teachers; However, this research is different from all existing research based on its scope, which leads to teachers' TPACK ability during the implementation of online learning during the pandemic. The seven constructs of TPACK are comprehensive because they recognize the interaction between content, pedagogy, and technology during online learning. The following chart describes the majority of primary school teachers in North Sulawesi implementing online learning during the pandemic.

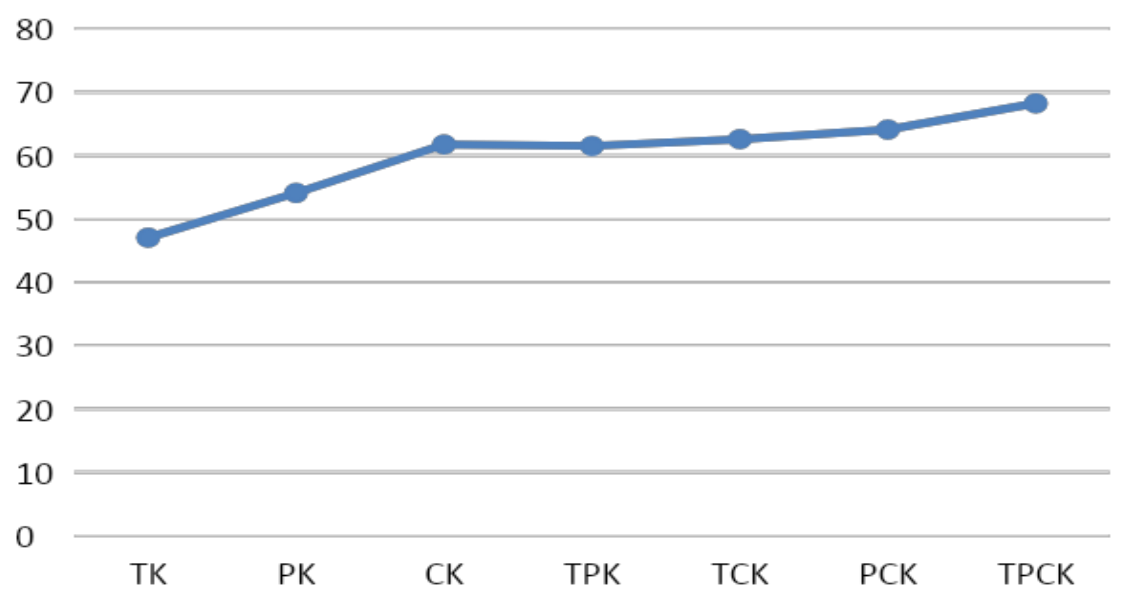

Figure 1. The average percentage of TPACK ability level of primary school teachers

From Figure 1., the chart displays the average percentage of the TPACK ability level of primary school teachers in North Sulawesi Province. The number shows that online learning is currently almost above the average for all TPACK components. The results showed that for each TPACK framework, the lowest percentage was found in the TK dimension of $47.04 \%$ and PK of $54.09 \%$. Besides, it can be seen that TPCK hits the highest percentage dimension of $68.24 \%$ and PCK of $64.10 \%$. The other TPACK framework domains are in the average percentage, including CK (61.76\%), TPK (61.51\%), TCK (63.59\%). The questionnaire reported that primary school teachers in North Sulawesi consider their technology knowledge (TK) as the weakest of the seven TPACK components. Based on the calculation results, it can be concluded that the research results show that the overall average ability of the teachers in the seven TPACK frameworks is $58.12 \%$, with sufficient criteria. Overall, it shows that most elementary school teachers already have TPACK competencies in online learning at this time. The competency of TPACK for elementary school teachers is in need to improve each TPACK framework construction, especially on the ability of Technology Knowledge (TK) and Pedagogical Knowledge (PK) for elementary school teachers in North Sulawesi province as the findings of Chai et al. (2012) found that Technology Knowledge (TK) and Pedagogical Knowledge (PK) were all significant predictors of TPACK.

Correlation between TPACK framework Construction of primary school teachers in online learning

Table 1. Descriptive Analysis Technology Knowledge (TK)

\begin{tabular}{lcc}
\hline \multicolumn{1}{c}{ Item } & $M$ & $S d$ \\
\cline { 2 - 3 } I keep up with technology that can be used in learning & 4.43 & .577 \\
I know various technologies & 4.02 & .601 \\
TK I cannot quickly learn new technology & 3.31 & 1.029 \\
I can use technology when teaching & 4.22 & .559 \\
I do not have technical skills in using technology & 3.91 & .702 \\
If I have technical problems related to the use of technology, I am not able to solve them & 3.09 & 1.050 \\
myself & & \\
\hline
\end{tabular}

Based on Table 1, it can be seen that most of the teachers agree upon the average primary school teachers' perception of the ability of technology knowledge (TK). This shows that elementary school teachers have mastery of technology seen based on the perception of "following technological developments (47.67\%)", "knowing various technologies (55.13\%)", "being able to use technology (55.46)" in 
Jurnal Prima Edukasia, 9 (1), 2021 - 89

Junita Cristi Makawawa, et al

online learning. However, teachers also answered "doubt" for their perceptions of solving technical problems on the use of technology (53.36\%) and studying technology (36.78). As mentioned in the findings section of this study, teachers have little expertise and knowledge about educational technology and computer technology in general. These findings also suggest that appropriate teacher training is essential as an alternative to mastering right technology for teachers in classroom learning.

Table 2. Descriptive Analysis of Pedagogical Knowledge (PK)

\begin{tabular}{lcc}
\hline \multicolumn{1}{c}{ Item } & M & SD \\
\hline I know the learning styles of the students I teach & 4.32 & .536 \\
I know the initial abilities of the students I teach & 4.17 & .591 \\
I study the characteristics of the students I teach & 4.24 & .519 \\
I did not analyze the results of student learning to find out student difficulties & 4.16 & .742 \\
I communicate with students to find out students 'difficulties in learning & 4.50 & .519 \\
I examine students' difficulties in learning & 4.28 & .506 \\
I did not make lesson plans before learning & 4.38 & .668 \\
I developed lesson plans following Permendikbud No.22 about the standard process & 4.15 & .519 \\
I use when doing the learning RPP & 4.31 & .725 \\
I can implement the RPP well in class & 3.97 & .701 \\
I can use a variety of learning approaches that help students learn & 4.14 & .507 \\
I can adapt different teaching styles to students, which differ by their characteristics & 4.08 & .559 \\
I give more attention to students who experience many difficulties in learning & 4.21 & .570 \\
I know how to organize and manage the class well & 4.08 & .544 \\
I do not know how to assess the performance of students in the classroom & 4.02 & .616 \\
I use a variety of methods and techniques in evaluating the learning process and results & 4.10 & .515 \\
from students &
\end{tabular}

Table 2 shows elementary school teachers' perception that most of them have competent Pedagogical Knowledge (PK). The average perception of the teacher's answer agreed that they "know the student's learning style (52.8\%), know the students' initial abilities (49.84\%), know the characteristics of students $(56.73 \%)$, learn the difficulties, student learning $(50.95 \%)$ and how to communicate with students (49.24\%) ". Apart from that, it is related to the ability to make (46.02\%), develop (55.69\%) and implement lesson plans properly in the classroom based on the standards of the process $(55.8 \%)$, organize and useful class management $(56.69 \%)$. They also agreed that they could adapt to different learning styles $(54.72 \%)$, used various methods and techniques in evaluating student learning processes and outcomes $(63.58 \%)$, and how to assess student performance in class $(61.6 \%)$.

Table 3. Descriptive Analysis Content Knowledge (CK)

\begin{tabular}{clcc}
\hline \multirow{2}{*}{ CK } & \multicolumn{1}{c}{ Item } & $M$ & $S D$ \\
\cline { 2 - 4 } & I have knowledge in elementary school with good learning & 4.08 & .458 \\
& I can not use knowledge in solving various problems in learning the elementary school. & 3.99 & .650 \\
\hline
\end{tabular}

Based on Table 3, the average answer of the teacher's perception is most of the abilities content knowledge $(\mathrm{CK})$ agree that they already have mastery of content knowledge in elementary school learning (64.38\%) and the ability to solve various problems in elementary school learning (59.15\%).

Table 4. Descriptive Analysis of Technology Pedagogical Knowledge (TPK)

\begin{tabular}{llrr}
\hline & \multicolumn{1}{c}{ Item } & $M$ & $S D$ \\
\cline { 2 - 3 } & I know the technology that I can use to build understanding and explore the learning & 3.97 & .516 \\
of elementary school & 4.01 & .482 \\
I can choose technology that fits a learning approach in teaching & 4.07 & .553 \\
TPK $\quad$ I can choose the right technology so that learning can run efficiently & 4.05 & .555 \\
I can take advantage of specific technologies that students can explore independently & .491 \\
I think more deeply about how technology affects the learning approach I use in the & 3.98 & .528 \\
classroom & 3.92 \\
\hline
\end{tabular}

Based on table 4, the average response perception of the majority of primary school teachers on the ability of Technology Pedagogical Knowledge (TPK) answered disagree on their ability of Techno- 
Jurnal Prima Edukasia, 9 (1), 2021 - 90

Junita Cristi Makawawa, et al

logy Pedagogical Knowledge (TPK) visits by perception "I can choose the right technology so that learning runs efficiently (55.65\%)", "I can choose suitable technology in the learning approach (65.16\%)", "I can use technology so that students explore learning (58.58\%) "," I know using technology to build students' understanding $(60.56 \%)$, "I can visualize the concept of learning with technology $(61.55 \%) "$.

Table 5. Descriptive Analysis Technology Content Knowledge (TCK)

\begin{tabular}{llcc}
\hline \multirow{3}{*}{ TCK } & \multicolumn{1}{c}{ Item } & $M$ & $S D$ \\
\cline { 2 - 4 } & I can use technology to solve the problem of learning in elementary school & 3.92 & .575 \\
& I cannot structure the learning stage well. & 4.02 & .525 \\
\hline
\end{tabular}

Based on Table 5, the table shows that the average mean answers to most of the perceptions of elementary school teachers on the ability of technology content knowledge (TCK) answered consistently; it can be seen from the statement, "Teachers can use technology to solve learning problems (63.62\%)". This is in line with the negative statement of their disagreement that "teachers are not able to arrange the learning path as well (66.28\%)

Table 6. Descriptive Analysis of Pedagogical Content Knowledge (PCK)

\begin{tabular}{lll}
\hline \multicolumn{1}{c}{ Item } & $M$ & \multicolumn{1}{c}{$S D$} \\
\hline I have a piece of useful knowledge about the causes of a rigid material studied & 3.85 & .478 \\
I can easily map topics that are difficult for students to learn. & 3.86 & .556 \\
I can to identify students' prior knowledge & 4.01 & .464 \\
I have a good knowledge of the necessary competencies to be achieved following the & 3.97 & .482 \\
teaching in elementary school curriculum revision in 2013 & 3.97 & .540 \\
PCK I can to design learning according to the curriculum standards in 2013 revised & 4.06 & .378 \\
I can prepare indicators of achieving necessary competencies well & 4.02 & .491 \\
I can carry out assessments following the assessment standards applied to the 2013 & 3.88 & .494 \\
curriculum revised & 3.97 & .434 \\
I have good knowledge of the 2013 curriculum revised & \\
I can teach by combining learning in elementary school, technology, and a specific \\
learning approach
\end{tabular}

Table 6 shows the average response perception of some elementary school teachers in the ability of Pedagogical Content Knowledge (PCK) answered agreed that they already have a good knowledge of the material intricate to teach $(66.77 \%)$, can map (59.46\%), designing (57.34\%) and compiling (74.32\%) teaching materials or competency achievement indicators $(61.85 \%)$, and combining elementary learning approaches with technology $(67.76 \%)$, able to identify the ability of students $(67.59 \%)$, and have a good knowledge of the 2013 curriculum (59.32\%) and be able to carry out assessments according to the 2013 curriculum assessment standards (59.32\%).

Table 7. Descriptive Analysis Technology Pedagogical Content Knowledge (TPCK)

\begin{tabular}{llcc}
\hline & \multicolumn{1}{c}{ Item } & $\boldsymbol{M}$ & \multicolumn{1}{c}{$\boldsymbol{S D}$} \\
\cline { 2 - 4 } & \multicolumn{1}{c}{ I can choose the technology that matches the material, how to teach } \\
them and what material students will learn & 4.09 & .455 \\
TPCK & 3.99 & .517 \\
$\begin{array}{l}\text { I can apply technology in assessing the learning process } \\
\text { I can apply technology in assessing student learning outcomes. }\end{array}$ & 3.99 & .425 \\
$\begin{array}{l}\text { I can choose the technology that is suitable for a learning approach } \\
\text { in teaching }\end{array}$ & 4.01 & .482 \\
\hline
\end{tabular}

Based on Table 7, it can also be seen that the perception of the ability of Technology Pedagogical Content Knowledge (TPK) towards online learning elementary school teachers agree. They stated that "they can choose technology that fits the material and teaching method $(68.16 \%)$ as well as technology that is following the learning approach (63.79\%)", and "can apply technology in conducting assessments in the process $(73.23 \%)$ and learning outcomes $(65.16 \%)$ ". Therefore, based on their perceptions, it can be said that elementary school teachers have the ability of Technology Pedagogical Content Knowledge (TPCK). This means that teachers make decisions regarding how to choose, adapt, and apply appropriate materials, pedagogy, and technology that can provide meaningful value to learning with classroom technology, which leads to student-centred learning in the implementation of online learning in elementary school 
Jurnal Prima Edukasia, 9 (1), 2021 - 91

Junita Cristi Makawawa, et al

Table 8. Relationships between perception TPACK frame construction

\begin{tabular}{|c|c|c|c|c|c|c|c|c|}
\hline \multicolumn{9}{|c|}{ Correlations } \\
\hline & & TK & $\mathrm{PK}$ & $\mathrm{CK}$ & TPK & TCK & PCK & TPCK \\
\hline \multirow{3}{*}{ TK } & Pearson Correlation & 1 & $.474^{* * *}$ & $.373^{* *}$ & $.383^{* *}$ & $.265^{* *}$ & $.265^{* *}$ & $.357^{* *}$ \\
\hline & Sig. (2-tailed) & & .000 & .000 & .000 & .004 & .004 & .000 \\
\hline & $\mathrm{N}$ & & 117 & 117 & 117 & 117 & 117 & 117 \\
\hline \multirow{3}{*}{ PK } & Pearson Correlation & & 1 & $.567^{* *}$ & $.620^{* *}$ & $.526^{* *}$ & $.526^{* *}$ & $.606^{* *}$ \\
\hline & Sig. (2-tailed) & & & .000 & .000 & .000 & .000 & .000 \\
\hline & $\mathrm{N}$ & & & 117 & 117 & 117 & 117 & 117 \\
\hline \multirow{3}{*}{ CK } & Pearson Correlation & & & 1 & $.506^{* *}$ & $.535^{* *}$ & $.535^{* *}$ & $.335^{* *}$ \\
\hline & Sig. (2-tailed) & & & & .000 & .000 & .000 & .000 \\
\hline & $\mathrm{N}$ & & & & 117 & 117 & 117 & 117 \\
\hline \multirow{3}{*}{ TPK } & Pearson Correlation & & & & 1 & $.592^{* *}$ & $.592^{* *}$ & $.802^{* *}$ \\
\hline & Sig. (2-tailed) & & & & & .000 & .000 & .000 \\
\hline & $\mathrm{N}$ & & & & & 117 & 117 & 117 \\
\hline \multirow{3}{*}{ TCK } & Pearson Correlation & & & & & 1 & $1,000^{* *}$ & $.470^{* *}$ \\
\hline & Sig. (2-tailed) & & & & & & .000 & .000 \\
\hline & $\mathrm{N}$ & & & & & & 117 & 117 \\
\hline \multirow{3}{*}{ PCK } & Pearson Correlation & & & & & & 1 & $.470^{* * *}$ \\
\hline & Sig. (2-tailed) & & & & & & & .000 \\
\hline & $\mathrm{N}$ & & & & & & & 117 \\
\hline \multirow{3}{*}{ TPCK } & Pearson Correlation & & & & & & & 1 \\
\hline & Sig. (2-tailed) & & & & & & & \\
\hline & $\mathrm{N}$ & & & & & & & \\
\hline
\end{tabular}

The results of the correlation between the TPACK constructs showed a strong positive correlation between PK-TPK $(r=0.620)$; PK - TPCK $(r=0.606)$; PK - CK $(r=0.567) ;$ PK - TCK $(r=0.526)$; PK - PCK $(\mathrm{r}=0.526)$; CK - TCK $(\mathrm{r}=0.535)$; CK - PCK $(\mathrm{r}=0.535)$; CK - TPK $(\mathrm{r}=0.506)$; TPK - TPCK $(r=0.802)$; TPK - PCK $(r=0.592)$; TPK - TCK $(r=0.592)$; TCK- PCK $(r=1,000)$. In Table 10, it is also seen that the correlation between moderate Correlation TK $-\mathrm{PK}(\mathrm{r}=0.474)$; TK $-\mathrm{TPK}(\mathrm{r}=0.383)$; TK - CK $(r=0.373)$; TK - TPCK $(r=0.357)$; TK - TCK $(r=0.265)$; TK - PCK $(r=0.265)$; $\mathrm{CK}-$ TPCK $(r=0.335)$; TCK - TPCK $(r=0.470)$; PCK - TPCK $(r=0.470)$, and others show weak and negative correlation. Thus, the PK and TPK components significantly affect TPACK elementary school teachers' perception of online learning today. These findings suggest that teachers emphasize their TPACK skills and abilities on the relationship between PK and TPK more closely related to their daily online teaching practices (Chuang \& Ho, 2011; Gao, Choy, Wong, \& Wu, 2009; Lim \& Chai, 2008). A study investigating TPACK primary school teachers' development has reported similar quantitative analysis results (Chai et al., 2013; Jang \& Tsai, 2012). The study reported that PK had the greatest impact in predicting the TPACK level of primary school teachers and concluded that increasing PK was the basis for developing TPACK. As teachers develop a basic PK level, they build a strong knowledge base from which the idea of effective technology integration can develop.

Conversely, when Sahin (2011) examined teachers' perceptions of general TPACK, they found TCK had a more considerable positive correlation than TPK. Therefore, as Greenhow, Dexter, and Hughes (2008) reported, teachers tend to create and integrate technology by representing technology's pedagogical abilities. We can assume that primary school teachers tend to focus first on their pedagogical knowledge of technology. We can support this statement with the correlation between the TPACK framework; we remember that PK and TPK contribute more significantly to TPACK primary school teachers (Liu \& Kleinsasser, 2015). Besides, in line with the literature on integrating technology into learning that we have previously mentioned, the results of kindergarten teachers give rise to the perception that primary school teachers have difficulty connecting their technological knowledge with content in current online learning (Koehler et al., 2013; Ricardo, 2019). However, they agreed to integrate technology with mathematics content and integrate this technology in mathematics teaching and learning, especially in implementing online learning during a pandemic. 
Jurnal Prima Edukasia, 9 (1), 2021 - 92

Junita Cristi Makawawa, et al

Significant differences between TPACK primary school teachers based on gender

Table 9. Relationship between TPACK and Gender

\begin{tabular}{ccc}
\hline Variable & Sig. (2-tailed) & Pearson Correlation \\
\hline Value of TPACK Gender & .237 & .110 \\
\hline
\end{tabular}

The results showed no significant difference between gender and their perceptions of all TPACK sub-domains (TK, CK, PK, PCK, TCK, TPK, TPACK) school teachers' basic. In this case, it was found that gender was not a significant factor for the perception of TPACK among elementary school teachers (Pamuk et al., 2013). Because these results were not statistically significant, some comparison groups and effect sizes were not mentioned.

Table 10. Comparison of the TPACK component between gender

\begin{tabular}{|c|c|c|c|c|c|}
\hline & Gender & Mean & $S D$ & $t$-testt-test & Sig \\
\hline \multirow{2}{*}{ TK } & male & 23.37 & 3.002 & \multirow{2}{*}{.83} & \multirow{2}{*}{.929} \\
\hline & female & 22.87 & 2.707 & & \\
\hline \multirow{2}{*}{ PK } & male & 68.41 & 6.046 & \multirow{2}{*}{1.47} & \multirow{2}{*}{.252} \\
\hline & female & 66.73 & 4.892 & & \\
\hline \multirow{2}{*}{ CK } & male & 8.26 & .712 & \multirow{2}{*}{$1: 31$} & \multirow{2}{*}{.591} \\
\hline & female & 8.01 & .906 & & \\
\hline \multirow{2}{*}{ TPK } & male & 24.11 & 3.178 & \multirow{2}{*}{.23} & \multirow{2}{*}{.350} \\
\hline & female & 23.98 & 2.403 & & \\
\hline TCK & male & $\begin{array}{l}\text { 8:04 } \\
7 \text { :01 }\end{array}$ & .898 & .68 & .882 \\
\hline \multirow[b]{2}{*}{ PCK } & male & 36.30 & $\begin{array}{l}.850 \\
2.447\end{array}$ & \multirow[b]{2}{*}{1.36} & \multirow[b]{2}{*}{.153} \\
\hline & female & 35.38 & 3.245 & & \\
\hline \multirow{2}{*}{ TPCK } & male & 15.96 & 1.971 & \multirow{2}{*}{-.46} & \multirow{2}{*}{.478} \\
\hline & female & 16.12 & 1452 & & \\
\hline
\end{tabular}

The Table 10 shows the small positive effect of gender variables on TK, PK, CK, TPK, TCK, PCK, and a small negative effect on TPCK. Therefore, when primary school teachers 'perceptions of TPACK were categorized by gender, further analysis found that gender only had a positive effect on teachers' perceptions of the factors involved with technology such as TK $(0.93)$, TPK $(0.35)$, TCK $(0.88)$ (Lin et al., 2012). On the other hand, several other findings show that on average, men have a higher success rate in other dimensions of TPCK such as PK, TK, CK, TPK, TCK, and PCK than women (Baylor, Shen \& Huang, 2003; Kurt, 2018; Tokmak, 2013). The results showed that female teachers in elementary schools in online learning implementation tend to feel less confident in applying technology in teaching than male teachers (Lin et al., 2012; Reyes et al., 2016). It is suggested that primary school teachers can put more effort into online learning for female teachers to be experienced with educational technology and computer technology in primary schools. Therefore, there is a need for future studies to create professional development programs to promote pedagogical knowledge and technology-related content of female primary school teachers.

\section{Conclusion}

The research results show that most of the primary school teachers in North Sulawesi already have the TPACK competencies needed in online learning today. Even so, TPACK competencies still need to be improved in the abilities of TK and PK. The correlation results between the TPACK constructs also showed that the PK and TPK components had a significant effect on TPACK Elementary School Teachers' perception of online learning today. It was also found that there was no significant difference between gender and TPACK competency of elementary school teachers. Therefore, to maximize student learning by providing quality online learning experiences, a good mastery of TPACK is required. Technology can only be a useful tool in primary school learning if it increases learning opportunities and learning actualization is significant. Therefore, it becomes more important than when and how technology will be used by teachers and the extent to which the teacher training process must be updated continuously in their mastery of TPACK competencies and provided regularly in schools' applications. 
Jurnal Prima Edukasia, 9 (1), 2021 - 93

Junita Cristi Makawawa, et al

\section{References}

Allen, E. J. Seaman, R. Poulin, and T. Taylor Straut (2016). Online report card: Tracking online education in the United States. L. Babson Survey Research Group and Quahog Research Group. Retrieved from http://onlinelearningsurvey.com/reports/onlinereportcard.pdf

Baylor, A., Shen, E. \& Huang, X. (2003). Which pedagogical agent do learners choose? The effects of gender and ethnicity. In A. Rossett (Ed.), Proceedings of E-Learn 2003--World Conference on ELearning in Corporate, Government, Healthcare, and Higher Education (pp. 1507-1510). Phoenix, Arizona, USA: Association for the Advancement of Computing in Education (AACE).

Baran, E., Chuang, H., \& Thompson, A. (2011). TPACK: An emerging research and development tool for teacher educators. Turkish Online Journal of Educational Technology, 10(4), 370-377

Çetin, İ. \& Erdoğan, A.(2018). Development, validity, and reliability study of technological pedagogical content knowledge (TPACK) efficiency scale for mathematics teacher candidates. International Journal of Contemporary Educational Research, 5(1), 50-62.

Cejas-León, R., Navío-Gámez, A., \& Barroso-Osuna, J. (2016). The university teacher's abilities from the tpackmodel (technological and pedagogical content knowledge).Pixel-Bit: Revista de Medios y Educación, 49,105-119. https://doi.org/10.12795/pixelbit.2016.i49.07

Chai, C. S., Koh, J. H. L., \& Tsai, C.-C. (2013). A review of technological pedagogical content knowledge. Education Technology and Society, 16(2), 31-51

Chuang, H., \& Ho, C. (2011). An investigation of early childhood teachers' technological pedagogical content knowledge (TPACK) in Taiwan. Journal of Kirsehir Education Faculty, 12(2), 99-117.

Cox, S., \& Graham, C. R. (2009). "Diagramming TPACK in practice: using and elaborated model of the TPACK framework to analyze and depict teacher knowledge." TechTrends, 53(5), 60-69.

Duveskog, M., Tedre, M., Sedano, C. I., \& Sutinen, E. (2012). Life planning by digital storytelling in a primary school in rural Tanzania. Journal of Educational Technology \& Society, 15(4), 225-237

Fraenkel, J. R., \& Wallen, N. E. (2006). How to design and evaluate research in education (6th ed.). New York, NY: McGraw-Hill.

Gao, P., Choy, D., Wong, A. F. L., \& Wu, J. (2009). Developing a better understanding of technologybased pedagogy. Australasian Journal of Educational Technology, 25(5), 714-730

Gray, D. (2010). Doing research in the real world. Thousand Oaks, CA: SAGE Publications.

Graham, C.R. (2011). Theoretical considerations for understanding technological pedagogical content knowledge (TPACK). Computers \& Education, 57(3), 1953-1960. Elsevier Ltd. Retrieved October 15, 2020, from https://www.learntechlib.org/p/50791/.

Greenhow, C., Dexter, S., \& Hughes, J. E. (2008). Teacher knowledge about technology integration: An examination of inservice

and preservice teachers' instructional decision-making. Science Education International, 19(1), 9-25.

Gu, X., Zhu, Y., \& Guo, X. (2013). Meeting the "digital natives": Understanding the acceptance of technology in classrooms. Journal of Educational Technology \& Society, 16(1), 392-402

Harrington \& Donald A. Loffredo (2010) Insight, Rumination, and Self-Reflection as Predictors of Well-Being, The Journal of Psychology: Interdisciplinary and Applied, 145:1, 39-57, DOI: $10.1080 / 00223980.2010 .528072$

Hsueh-Hua, C., \& Chao-Ju, H. (2011). An investigation of early childhood teachers' technological pedagogical content knowledge (TPACK) in Taiwan. Journal of Kirsehir Education Faculty, 12(2), 99-117

Jang, S.-J., \& Tsai, M.-F. (2012). Exploring the TPACK of Taiwanese elementary mathematics and science teachers with respect to use of interactive whiteboards. Computers \& Education, 59(2), 327-338. doi:10.1016/j.compedu.2012.02.003

J Flood, Shirley B. H., \& Lapp .(2015). Handbook of research on teaching literacy through the communicative and visual arts. https://doi.org/10.4324/9781315759616.

Ke, F., \& Hoadley, C. (2020). Evaluating Online learning communities author(s): Fengfeng Ke and Christopher Hoadley Source : Educational Technology Research and Development, Vol . 57, No. 
Jurnal Prima Edukasia, 9 (1), 2021 - 94

Junita Cristi Makawawa, et al

4 (Aug., 2009 ), pp. Published by: Springer Stable URL : https://www.jstor.org/stable/40388644

Kurt, S. (2018). Technological pedagogical content knowledge (TPACK) framework. From https://educationaltechnology.net/technological-pedagogical-content-knowledge-tpackframework/.

Koehler, M. J., \& Mishra, P. (2009). What is technological pedagogical content knowledge? Contemporary Issues in Technology and Teacher Education (CITE Journal), 9(1), 60-70.

Koehler, M. J., Mishra, P., \& Cain, W. (2013). What is technological pedagogical content knowledge (TPACK)? Journal of Education, 193(3), 13-19. doi:10.1177/002205741319300303.

Landry, A. (2010). Creating and validating an instrument to measure middle school mathematics teachers' technological pedagogical content knowledge (TPACK). Trace: Tennessee Research and Creative Exchange.

Lenters, K., \& Winters, K. (2013). Fracturing writing spaces: Multimodal storytelling ignites process writing. The Reading Teacher, 67(3), 227-237

Lim, C. P., \& Chai, C. S. (2008). Teachers' pedagogical beliefs and their planning and conduct of computer-mediated classroom lessons. British Journal of Educational Technology, 39(5), 807828.

Lin, T.-C., Tsai, C.-C., Chai, C. S., \& Lee, M.-H. (2012). Identifying science teachers' perceptions of technological pedagogical and content knowledge (TPACK). Journal of Science Education and Technology, 22(3), 325-336. doi:10.1007/s10956-012-9396-6

Liu, M. H., \& Kleinsasser, R. C. (2015). Exploring EFL teachers' call knowledge and competencies: Inservice program perspectives. Language Learning and Technology,19(1), 119-138.

Mishra, P., \& Koehler, M. J. (2006). Technological pedagogical content knowledge: a framework for teacher knowledge. Teachers College Record, 108, 1017-1054.

Moore, J. L., Dickson-Deane, C., \& Galyen, K. (2011). E-Learning, online learning, and distance learning environments: Are they the same? Internet and Higher Education. https://doi.org/10.1016/j.iheduc.2010.10.001

Orlando, J., \& Attard, C. (2016). Digital natives come of age: the reality of today's early career teachers using mobile devices to teach mathematics. Mathematics Education Research Journal, 28(1), $107-121$

OECD. (2010). Inspired by technology, driven by pedagogy: A systemic approach to technology-based school innovations. Santa Catarina: OECD Publishing.

Ozudogru, M., \& Ozudogru, F. (2019). Technological Pedagogical Content Knowledge of Mathematics Teachers and the Effect of Demographic Variables. Contemporary Educational Technology, 10(1), 1-24. https://doi.org/10.30935/cet.512515.

Pamuk, S., Ergun, M., Cakir, R., Yilmaz, H. B., \& Ayas, C. (2013). Exploring relationships among TPACK components and development of the TPACK instrument. Education and Information Technologies, 1-23.

Reyes Jr., V. C., Reading, C., Rizk, N., Gregory, S., \& Doyle, H. (2016). An exploratory analysis of TPACK perceptions of pre-service science teachers. International Journal of Information and Communication Technology Education, 12(4), 1-14. doi:10.4018/ijicte.2016100101

Ricardo, S., (2019). TPACK: Technological, Pedagogical, and Content Model Necessary to Improve the Educational Process on Mathematics through a Web Application?. International Electronic Journal of Mathematics Education. doi: 10.29333/iejme/5887.

Sahin, I. (2011). Development of survey of technological pedagogical and content knowledge (TPACK). Turkish Online Journal of Educational Technology, 10(1), 97-105

Sher, W., Williams, A., \& Northcote, M. (2015). The lived experience of online educators: Insights from construction management. Construction Economics and Building, 15(2), 49-62. doi:10.5130/ajceb.v15i2.4398

Scoble, R., Israel, S., \& Benioff, M. (2014). Age of context: Mobile, sensors, data, and the future of privacy. United States: Patrick Brewster Press. 
Jurnal Prima Edukasia, 9 (1), 2021 - 95

Junita Cristi Makawawa, et al

Shafer, K. G. (2008). Learning to teach with technology through an apprenticeship model. Contemporary Issues in Technology \& Teacher Education, 8(1), 27-44.

So, H., \& Kim, B. (2009). Learning about problem-based learning: Student teachers integrating technology, pedagogy and content knowledge. Australasian Journal of Educational Technology, 25(1), 101-116.

Sobel, K., \& Grotti, M. G. (2013). Using the TPACK framework to facilitate decision making on instructional technologies. Journal of Electronic Resources Librarianship, 25(4), 255-262. DOI: 10.1080/1941126X.2013.847671.

Scoble, R., Israel, S., \& Benioff, M. (2014). Age of context: Mobile, sensors, data and the future of privacy (1st ed.). United States: Patrick Brewster Press.

Sher, W., Williams, A., Northcote, M. (2015). The lived experience of online educators: Insights from construction management. Construction Economics and Building, 15(2), 49-62. doi:10.5130/AJCEB.v15i2.4398.

So, H.-J. \& Kim, B. (2009). Learning about problem-based learning: Student teachers integrating technology, pedagogy, and content knowledge. Australasian Journal of Educational Technology, 25(1). https://doi.org/10.14742/ajet.1183

Schmidt, D. A., Baran, E., Thompson, A. D., Mishra, P., Koehler, M. J., \& Shin, T. S. (2009). Technological pedagogical content knowledge (TPACK). Journal of Research on Technology in Education, 42(2), 123-149. doi:10.1080/15391523.2009.10782544.

Tokmak, H. (2013). Changing preschool teacher candidates' perceptions about technology integration in a TPACK-based material design course. Education as Change, 17(1), 115-129. doi: 10.1080/16823206.2013.773927.

Tsai, S., \& Machado, P. (2001). E-learning, Online learning, web based learning, or distance learning : Unveiling the Ambiguity in Current Terminology. 2002, 3-5.

UNESCO. (2011). ICT competency framework for teachers version 2.0.

World Economic Forum. (2015). New vision for education unlocking the potential of technology. http://www3.weforum.org/docs/WEFUSA_NewVisionforEducation_Report2015.pdf

Wake, D., \& Whittingham, J. (2013). Teacher candidates' perceptions of technology-supported literacy practices. Contemporary Issues in Technology and Teacher Education,13(3), 175-206.

Zelkowski, J., Gleason, J., Cox, D. C., \& Bismarck, S. (2013). Developing and validating a reliable TPACK instrument for secondary mathematics preservice teachers. Journal of Research on Technology in Education, 46(2), 173-206. doi:10.1080/15391523.2013.10782618. 